\title{
Climates of the Earth and Cryosphere Evolution
}

\author{
Gilles Ramstein
}

Received: 18 March 2011/Accepted: 9 June 2011/Published online: 8 September 2011

(C) The Author(s) 2011. This article is published with open access at Springerlink.com

\begin{abstract}
The interrelationship between the cryosphere and the climate is not always operating on Earth over a scale of billions or millions of years. Indeed, most of the time, the Earth is regulated at temperatures such that no ice sheet exists. Nevertheless, it is very fruitful to understand the conditions where and when ice sheets were triggered during the Earth's history. This paper deals with the paleoclimate and the cryosphere in the last $4.6 \mathrm{Ga}$ and explains the different processes that make the climate of the first 4 billion years warm despite the weaker solar luminosity. We also describe the more recent evolution in the last 65 million years when a global decrease in atmospheric $\mathrm{CO}_{2}$ from around 4 PAL to 1 PAL was associated with a global cooling ( $1 \mathrm{PAL}$ present atmospheric level $=280 \mathrm{ppm}$ ). It is in this context that the Quaternary occurred characterized by low atmospheric $\mathrm{CO}_{2}$ and the presence of two perennial ice sheets in Greenland and Antarctica. The last million years are certainly the most documented since direct and reliable $\mathrm{CO}_{2}$ measurements are available. They are characterized by a complex climate/cryosphere dynamics leading to oscillations between long glacial periods with four ice sheets and shorter ones with only two ice sheets (interglacial). We are currently living in one of those interglacials, generally associated with a $\mathrm{CO}_{2}$ level of $280 \mathrm{ppm}$. Presently, anthropogenic activities are seriously perturbing the carbon cycle and the atmospheric $\mathrm{CO}_{2}$ content and therefore the climate. The last but not least question raised in this paper is to investigate whether the anthropogenic perturbation may lead to a melting of the ice sheets.
\end{abstract}

Keywords Paleoclimate - Thermal regulation - Onset of ice sheets · Climate/cryosphere modelling 


\section{Introduction}

We very often consider that we live in a warm climate. Through this travel in the deep ages of the Earth, we shall see that this idea is mostly wrong, depending on the timescale we are using. This paper aims at showing the relationships between the climate and the cryosphere during the Earth's history. A striking feature is that, most of the time, there is just no cryosphere at all. Periods when ice sheets developed are indeed very seldom (Frakes et al.

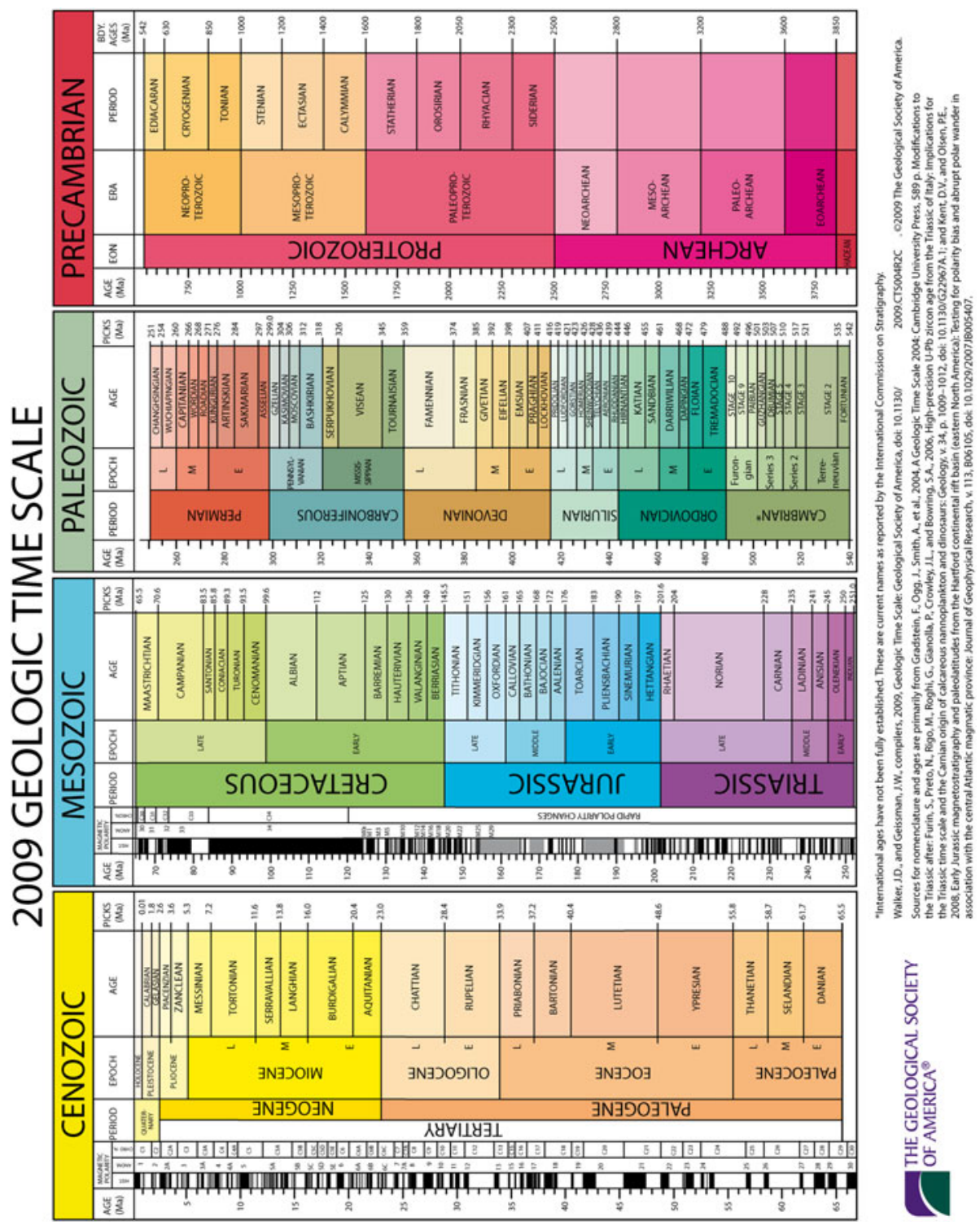

Fig. 1 Geological timetable in units of 1,000 years. From the Geological Society of America: http://www.geosociety.org/science/timescale/ 
1992). The most common climate state of our planet is in fact warm (see Fig. 1 for a geological timetable). Since the Precambrian explosion, $540 \mathrm{Ma}$ ago (Ma $=10^{6}$ years), the period that is best documented, the glacial periods are also very infrequent. For instance, the dinosaurs, which lasted very long (220-65 Ma), lived during warm climates without any ice sheet most of the time (Amiot et al. 2006). In contrast, the period where we presently live (the Quaternary) with two ice sheets (one in each hemisphere) in the last 2.6 Ma is indeed a cold period and one of the rare periods on the geological timescale where ice sheets did exist. Indeed, for more than $1 \mathrm{Ma}$, the climate has shifted from glacial $(80 \%)$ to interglacial (20\%). During the glacial period, four ice sheets existed. As well as Greenland and Antarctica, two extra ice sheets were located over the northern parts of North America (Laurentide) and over the north of Europe (Fennoscandia). In the most recent 14,000 years, we are in a warm interglacial climate (Holocene) during which human population has spread all over the world.

This paper not only considers the role of the cryosphere on past climate, but also deals with the future behaviour of the cryosphere under anthropogenic forcing. It discusses what we may infer as to the future evolution of Greenland and Antarctica beyond the twenty-first century, and whether the large and rapid increase in greenhouse gases may melt the ice sheets that normally survive during interglacial conditions. We shall also consider the thresholds and the scenarios that may lead to both the onset and decay of the ice sheets using coupled climate and cryosphere modelling.

\section{Precambrian Climate}

In the last $4.6 \mathrm{Ga}\left(\mathrm{Ga}=10^{9}\right.$ years), solar radiation has represented an unparalleled forcing factor for providing energy to the Earth. The Sun-this is certainly not the most poetic definition-is 'just' a nuclear fusion reactor, which "burns" its hydrogen into helium and then helium itself. The resulting evolution of the Sun's luminosity is well modelled (Gough 1981; Fig. 2) and shows an increase of $\sim 7 \%$ per each billion years (Ga). Therefore, $4.6 \mathrm{Ga}$ ago, the young Sun was a 'weak' Sun as compared to its present status. The implications

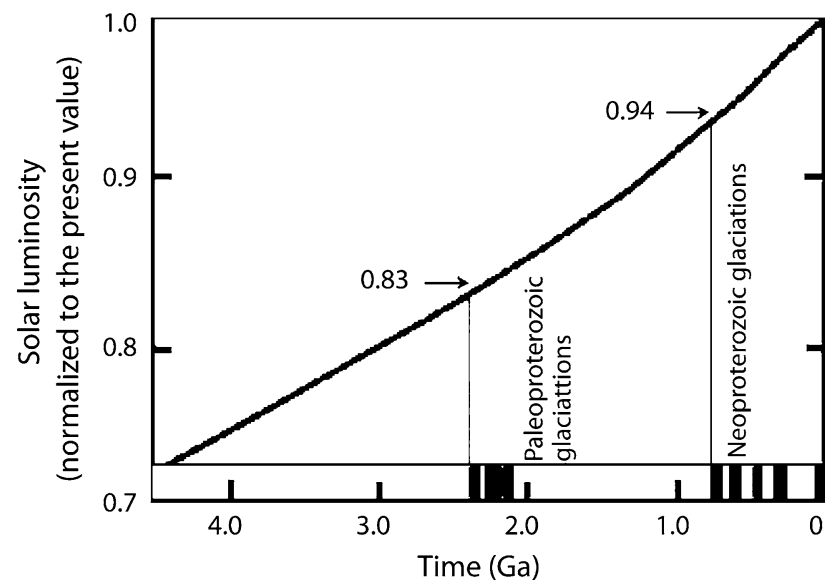

Fig. 2 Evolution of the Sun's luminosity with time in the last $4.6 \mathrm{Ga}$, as predicted by the computer model of Gough (1981). The increase is around 7\% every Ga. The young Earth therefore experienced a fainter Sun $\sim 30 \%$ less powerful $4.5 \mathrm{Ga}$ ago than at present 
for the Earth (but indeed also for Venus and Mars) are huge: first, because solar radiation is the main source of energy for the Earth system $(>99 \%)$ and second because we know that even the weak variations in solar radiation at the top of the atmosphere (that can reach seasonally 15\%), due to the orbital parameters of the Earth, have induced relatively large climatic variations during the Quaternary period (see Sect. 6 The last million year's climate). Consequently, the Earth should have experienced a drastic cooling due to this weak Sun: it should look like the frozen satellites of Jupiter and Saturn. In fact, geological and isotopic measurements demonstrate first that liquid water existed on the Earth's surface for at least $4 \mathrm{Ga}$, and second that during the Archaean (4.54-2.5 Ga) and the Proterozoic era (2.5-0.54 Ga) (Fig. 1), the Earth was warm with ocean temperatures ranging from 50 to $70^{\circ} \mathrm{C}$ (Robert and Chaussidon 2006). As to whether these temperatures really represent the Earth's surface temperature remains an open question. There are alternative views that question the temperatures deduced from isotopic values and suggest lower temperatures (Shields and Kasting 2007). This warm Earth situation raises an apparent contradiction: the so-called faint young Sun paradox. Although the greenhouse effect is accepted as the main process to counterbalance the weak young Sun, other interpretations (Rosing et al. 2010) do pinpoint the possibility of a rather cold Archaean climate. In that study, glaciation is avoided because of a lower Earth albedo resulting from the absence of continental mass (ocean albedos being much smaller than terrestrial ones) and because of biologically induced clouds (low-altitude clouds in the present day climate act as a cooling factor whereas this effect did not exist in the deep past). The linear increase in continental accretion results in a linear increase in the Earth's albedo all through the Archaean period. Both hypotheses (timing of the accretion and cloud properties) are puzzling (Flament et al. 2008). First they demonstrate that the relationship between continental accretion and albedo is not straightforward because the continents remain under the ocean surface during a very long period of time; their impact on albedo only becomes important after around $3 \mathrm{Ga}$. Second, the cloud properties during the Achaean are totally unconstrained. Rosing et al. (2010) are still very controversial.

If the greenhouse effect is able to counteract the low forcing of the weak Sun, the next question is to identify which greenhouse gas would be able to counterbalance the weak faint Sun. Following the original suggestion of Sagan and Mullen (1972), who identified $\mathrm{NH}_{4}$ as a possible candidate, most scientists agreed on identifying carbon dioxide as the most appropriate greenhouse gas. The volcanic source of $\mathrm{CO}_{2}$ must have been enhanced during the early Earth, whereas the sink of $\mathrm{CO}_{2}$, especially through silicate weathering, was much reduced because there was no or very little continental surface. Therefore, a high level of carbon dioxide in the atmosphere was very likely during the early Earth. However, large amounts of atmospheric carbon dioxide would have produced siderite $\left(\mathrm{FeCO}_{3}\right)$ on the continental surface (Rye et al. 1995). Unfortunately, none of the oldest rocks do show the presence of any siderite, which leads several authors (Kasting 2004) to suggest that $\mathrm{CO}_{2}$, by itself, could not "do the job" alone and that another greenhouse gas should have been involved. Methane has been suggested as an appropriate candidate, but the next question is what would be the possible sink and source of methane on Earth?

Something often forgotten about the Earth's atmosphere is that during about half of the 4.6 billion years of the Earth's history, the atmosphere was anoxic (deficient in oxygen). An oxygen increase in the atmosphere only occurred 2.2-2.4 billion years ago (Catling and Claire 2005; Bertrand 2005). This feature is largely accepted by the community, even if there are still some controversies (Ohmoto et al. 2006). Several lines of evidence (Knoll 2004) pinpoint the fact that methanogene archae appeared very early in the Tree of Life. Kasting (2004) developed a scenario where the source of methane on Earth, in opposition 
to the situation on Titan, can only be biological and most likely produced by these archae, which were very abundant in the ocean. Indeed, the surface temperature on the Earth is much higher than that of Titan, and the environmental conditions do not allow enough of the methane emitted by abiotic sources to be stored in the atmosphere at equilibrium.

What about the methane sink? Over the geological timescale, methane behaves as a "match". It can produce a strong warming because it is a powerful greenhouse gas (30 times more efficient than $\mathrm{CO}_{2}$ ), but its residence time in the oxic atmosphere is very short: about 10 years. Methane is oxidized and transformed into carbon dioxide, which is a less powerful greenhouse gas but one that lasts much longer in the atmosphere: several hundreds of years. This is illustrated in the scenario that has been proposed to explain the brutal warming of the Paleocene/Eocene era boundary, 55 million years ago (Dickens and Francis 2004). Many authors invoked, to explain large ${ }^{13} \mathrm{C}$ variations, the huge methane emissions due to the enormous quantity of methane hydrates stored within oceanic sediments. These hydrates are a solid form of methane, in which the $\mathrm{CH}_{4}$ molecules are inside a network of crystals as ice crystals. The phase diagram is such that a pressure decrease or a temperature increase can provoke a changing phase from solid hydrate $\mathrm{CH}_{4}$ to gaseous $\mathrm{CH}_{4}$ (Dickens 2003). The release of methane from the dissociation of the hydrate, highly depleted in $\delta^{13} \mathrm{C}^{1}$ around $-60 \%$, explains both the negative carbon excursion observed at the Paleocene/Eocene boundary and the subsequent abrupt warming (Zachos et al. 2001). This is the "match" effect of methane. Of course, in an anoxic atmosphere, the sink of methane is much less efficient. Therefore, both the methane source and sink processes discussed here support the possibility of a strong accumulation of methane in an anoxic atmosphere.

\section{Regulation-Deregulation of the Earth's Surface Temperature}

As described earlier, in a context where the Sun is fainter by a rather large amount $(-30 \%$ at $4.6 \mathrm{Ga}$ and $-6 \%$ at $0.6 \mathrm{Ga}$ with respect to the present-see Fig. 2), carbon dioxide most probably, and methane, would have helped to largely overcompensate the lower solar forcing and would explain the warm climates that the Earth enjoyed. Indeed, the Archaean and Proterozoic show very few evidences of glaciation. Recently, the existence of a Pongolian Glaciation ( $2.7 \mathrm{Ga}$ ) has been pointed out (Crowell 1999; Young et al. 1998). Subsequent glaciations occurred, taking account of error bars, synchronously with the atmospheric oxygen rise at $2.4-2.2 \mathrm{Ga}$, during the so-called Huronian glaciation. This is supported by the evidence of glaciation that has been found in Canada (Fig. 3). The third glaciation occurred more than $1.5 \mathrm{Ga}$ later during the Neoproterozoic. One can always argue that "the absence of evidence (of other glaciations) is not the evidence of absence". This remark is indeed valid when dealing with the deep past where we have only scarce data. Nevertheless, it appears that glaciations are only accidents on Earth, which is most of the time regulated by warm temperatures. But how does this regulation work? And why did these accidents occur?

1 The $\partial$ notation is defined by the formula:

$\partial \%=1000\left\{\frac{R \text { sample }}{R \text { standard }}-1\right\}$

where $R$ stands for isotopic ratio, for example: $\frac{\mathrm{C}^{13}}{\mathrm{C}^{12}}$ or $\frac{\mathrm{O}^{18}}{\mathrm{O}^{16}}$. 


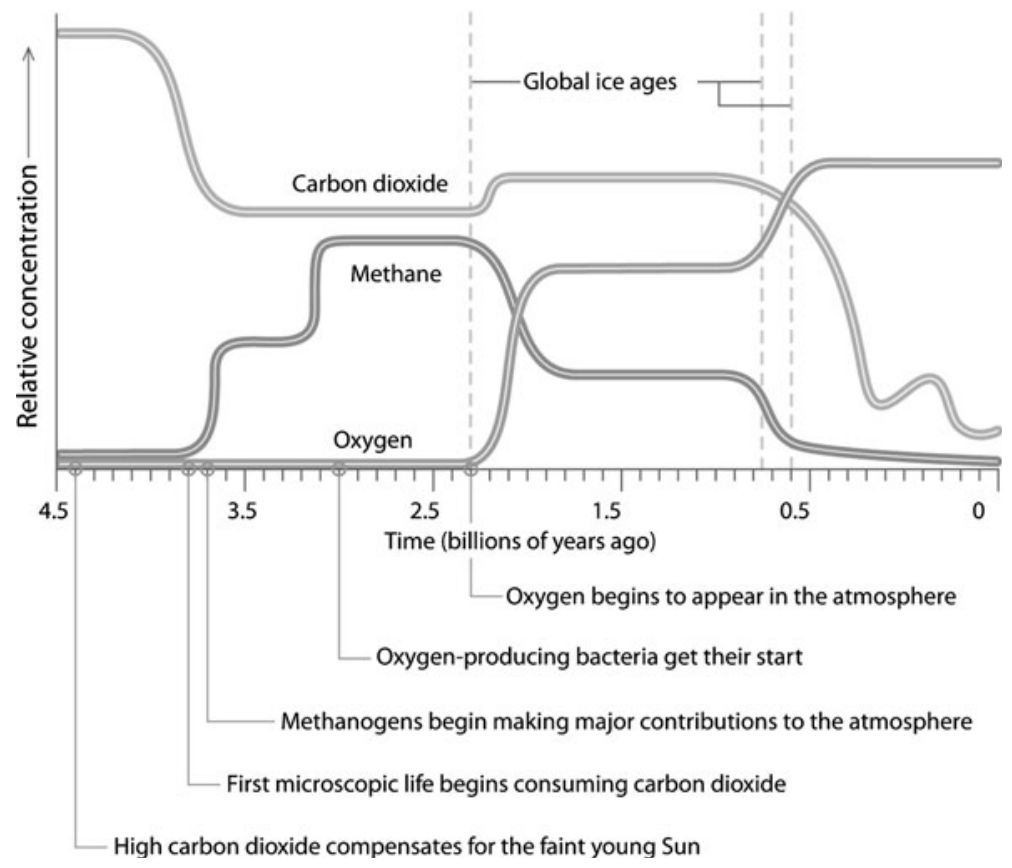

Fig. 3 Long-term evolution of the relative concentrations of $\mathrm{CO}_{2}$ and $\mathrm{CH}_{4}$, as well as of $\mathrm{O}_{2}$. To be noticed are (1) the rapid decrease in methane coinciding with an $\mathrm{O}_{2}$ rise, leading to the Huronian glaciation (2.2-2.4 Ga) and (2) the drop in $\mathrm{CO}_{2}$ at the beginning of the Neoproterozoic leading to major glaciation (750 Ma). (From Kasting 2004)

This regulation is not a new idea. Lovelock performed pioneering work showing that many processes including biology make the Earth able to "protect" itself against perturbations (Lovelock 1979). Nevertheless, similar to Wegener, with his continental drift theory, as long as appropriate and well-quantified mechanisms were not found to explain and support this assumption, many scientists remain skeptical of its validity. Long-term interactions between the climate, tectonics, and the carbon cycle may therefore be invoked for supporting the regulation of the Earth system (Walker et al. 1981).

It is indeed difficult, if not impossible, to infer what the climate was before the Late Heavy Bombardment event (Morbidelli et al. 2001) but, through all the period extending between $3.8 \mathrm{Ga}$ and the Precambrian (540 Ma), a regulation mechanism was powerful enough to maintain a warm climate despite a weaker Sun.

This mechanism is closely related to the carbon cycle at geological timescales. As to the source of carbon dioxide, recent publications (Cogné and Humler 2004) show that, for at least the last $100 \mathrm{Ma}$, there is no evidence that the quantity of carbon dioxide produced by volcanism has changed. It is indeed a very short time period as compared to 3 billion years but, in the absence of recorded variations for that period, we will be conservative and consider the source as constant and equal to the present day value. This hypothesis could be improved accounting for the variation in the heat flux at the Earth's surface (Mareschal and Jaupart 2006). In contrast, silicate weathering, which is the most powerful sink, is dependent on tectonics and therefore on paleogeography. If most of the continental mass is located in the equator/tropics area, the continents experience huge precipitation. The droplets including atmospheric carbon dioxide become acidic and dissolve silicate, which 
is transported by runoff to the ocean, and then sink in the form of carbonates with sediments at the bottom of the ocean, resulting in the decrease in atmospheric carbon dioxide. In contrast, if most of the continental mass is located at high latitudes, it will experience a dry climate because of low precipitation, resulting in a weak alteration and little erosion. This low weathering context would logically correspond to an increase in atmospheric carbon dioxide.

More than 90 years ago, soon after Wegener (1915) proposed his tectonic plate drift theory, Köppen and Wegener (1924) showed how it would impact the Earth climate on the long term. However, one major piece of reasoning was missing in that analysis. Not only the climate but also the carbon dioxide content is modified by tectonics through the feedback loop produced by the triptych climate/carbon dioxide/tectonics, which remarkably explains the existence of a warm climate most of the time. When the temperature increases, weathering also increases and carbon dioxide decreases; this leads to a cooling and vice versa. Therefore, carbon dioxide is a powerful thermo-regulator (Walker et al. 1981).

In spite of this feedback and regulation phenomenon, very rare deviations from this scenario do occur. As previously discussed, the Earth depends on methane and carbon dioxide to maintain warm temperatures through the greenhouse effect, thereby overcoming the cooling effect of a faint young Sun; this makes the possible occurrence of major glaciations, if the concentration of one of these gases suddenly decreases (Fig. 3): the Earth would become a "snowball". A striking point in Kasting's scenario (Kasting 2004) is the occurrence of a methane drop and of a simultaneous oxygen atmospheric rise corresponding to the so-called Huronian glaciation (2.2-2.4 Ga) (Fig. 3).

What are the causes of these accidents, and what determines their timing? The first one, which occurred 2.2-2.4 Ga ago, could be related to biological activity. The methanogene archae, which prevailed in the surface ocean since about $3.5 \mathrm{Ga}$, contributed to methane production in the Earth's atmosphere, whereas oxygen producers (cyanobacterias) were totally marginal. On the other hand, because methanogene archae cannot survive in an oxic environment, they had to immigrate to anoxic refugia when the level of oxygen increased. A strong point in Kasting's theory is that when the oxygen concentration rises as a result of oxygen producers' shifts from marginal to prevailing, the archaes disappeared, with the consequence of a sudden drop of atmospheric methane, therefore, triggering a major glaciation. It can therefore be concluded following Kasting that the first large glaciation (Huronian) was driven by a biological crisis and was "instantaneous" on the geological timescale.

\section{The Neoproterozoic Era Global Glaciation}

Certainly, the most documented 'snowball Earth' episodes are those of the Neoproterozoic Era. They consist of three main glaciations: the two oldest ones, the Sturtian (715 Ma) and the Marinoan (635 Ma), are supposed to be global (Hoffman et al. 1998; Hoffman and Schrag 2002), whereas the third and most recent one, the Rapitan glaciation (550 Ma), appears to be essentially regional and linked to the Appalachian uplift (Donnadieu et al. 2004b). Such global glaciations result from a 'rapid' decrease in the atmospheric $\mathrm{CO}_{2}$ content. Different lines of evidence are invoked in support of the existence of these temporary global glaciations: (1) paleomagnetism evidence for the presence of an ice sheet at low latitudes; (2) a strong decrease in $\delta^{13} \mathrm{C}$; (3) the reappearance, after $1.5 \mathrm{Ga}$ of absence 


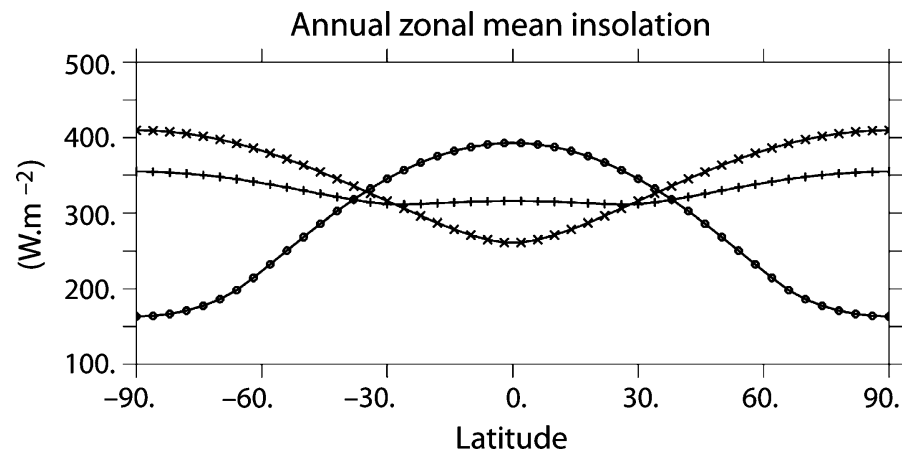

Fig. 4 Annual mean variation in insolation at the top of the atmosphere as a function of latitude, for different values of the Earth obliquity $90^{\circ}$ (crosses), $60^{\circ}$ (plus signs), and $23.5^{\circ}$ (dots). For high-obliquity values, the coldest zones are in the equatorial regions, while for the present obliquity of $23.5^{\circ}$, the polar regions are the coldest. (From Donnadieu et al. (2002); Yannick.Donnadieu@lsce.ipsl.fr, LSCE, France)

of banded-iron formations $\left(\mathrm{BIF}^{2}\right)$; and (4) huge cap carbonate formations overlaying glacial diamictites (tillites), which are typical glacial deposits. These observations were made by different research teams and, till the end of the last century, no reliable global explanation was available, which could help us to understand what was happening during the Neoproterozoic.

Concerning the unusual location of the ice sheet at equatorial latitudes and not in polar regions, a conclusion based on only few reliable paleomagnetic data, an attractive explanation was provided by Williams (1975) and, later on, theoretically demonstrated by Williams et al. (1998). Indeed, if the Earth did have at that time a much larger obliquity $\left(>60^{\circ}\right)$, it is easy to show (Fig. 4) that the lowest annual temperatures would have occurred over the equatorial regions. However, this simple explanation cannot be retained for two main reasons. First, Levrard and Laskar (2003) demonstrated that no realistic mechanism would be able to produce the large decrease in Earth's obliquity from a high value of $>60^{\circ}$ to its present-day low value of $\sim 23^{\circ}$. Moreover, Donnadieu et al. (2002) showed that such a high obliquity would lead to a huge seasonal cycle, which would be inconsistent with a large mid-latitude ice sheet during the Marinoan glaciation.

Further pioneering work was triggered by the American geologist Harland (1964) who proposed that glaciations in the tropics (as observed through geological evidences) should in fact be global. However, that explanation was not accepted by modellers. A global glaciation would have resulted in an increased albedo on the Earth: instead of being a 'blue planet' with a global albedo of 0.3 , the Earth would become a 'white planet' with a global albedo around 0.6-0.8. If such a snowball Earth did ever exist, it should still be here today because the only way to escape glaciation would be to increase the Sun's luminosity by a factor of 1.5, which is not possible. The solution to this conundrum came 30 years later when Kirschvink (1992) proposed that, during a snowball Earth episode, volcanism continues to be active and carbon dioxide continues to be emitted into the atmosphere. In contrast to the normal situation, where it interacts with the terrestrial biosphere and the

\footnotetext{
2 In an anoxic environment, $\mathrm{Fe}^{2}+$ is soluble in ocean water, whereas $\mathrm{Fe}^{3+}$ is insoluble. Therefore due to $\mathrm{Fe}^{2+}$ the iron can accumulate in the ocean as it does today at the bottom of the Red Sea. In oxic conditions both oxides are insoluble and iron can no more accumulate i.e. BIF disappeared at $1.8 \mathrm{Ga}$.
} 
ocean, $\mathrm{CO}_{2}$ would remain in the atmosphere. Because continents were covered by ice sheets and oceans by sea ice, carbon dioxide was therefore accumulated in the atmospheric reservoir until it was able, through a super-greenhouse effect, to melt the snowball Earth. This scenario is consistent with the other three observations listed previously.

As sea ice and land ice sheets completely inhibit the carbon cycle, carbon is no longer fractionated and the $\delta^{13} \mathrm{C}$ value remains very similar to its volcanic original value. As the ventilation of the ocean covered by sea ice completely declined, oxygenation of the ocean drastically decreased. Hence, the reappearance of banded iron formation that prevailed in the Archaean and in the early Proterozoic oceans when the ocean was anoxic and iron could accumulate and re-form the BIFs. Finally, after millions of years, the concentration of carbon dioxide reached a threshold value that resulted in a greenhouse effect strong enough to eventually produce a huge deglaciation, huge precipitation, and strong erosion. In such a very warm climate, a large amount of carbonates sunk into the oceans, explaining the paradox why tillite was overlaid by cap carbonates.

Hoffman's snowball Earth theory supported by these successes became very popular, in explaining most of the apparently paradoxical features that occurred during the Neoproterozoic Era. Nevertheless, many questions remained unsolved (Ramstein et al. 2004a). Why did carbon dioxide largely decrease after the Neoproterozoic perturbation and why was the Neoproterozoic not preceded by similar events during the first billion years of the Earth history? The answers to these questions were provided by Donnadieu et al. (2004a), thanks to a fruitful collaboration between geochemists and climate modellers (Goddéris et al. 2007).

Less than 10 years ago, the influence of paleogeography on $\mathrm{CO}_{2}$ was suggested in order to explain the large decrease in carbon dioxide. It was known for a long time that continents were oscillating between the building-up of a large supercontinent that subsequently broke into several smaller continents drifting away from each other. The last of these supercontinents was called "Pangaea" that broke up in the period extending between the Triassic and the Cretaceous (Fig. 1). The preceding one, of interest to us here, was called "Rodinia". It was sitting on the equatorial band and spread to $\pm 40^{\circ}$ (Fig. 5a); it was aggregated before $1 \mathrm{Ga}$ and began to break up only around 800-750 Ma (Fig. 5b; Donnadieu 2004a).

Very peculiar characteristics of that breakup ought to be stressed. While the initial supercontinent extended to low latitudes (Fig. 5a), most of its fragments after break-up remained in the tropical belt (Fig. 5b). Referring to the preceding discussions on how $\mathrm{CO}_{2}-$ climate-tectonics act together to regulate the temperature at the surface of the Earth, it is understandable that this post break-up configuration, where all the fragments remained in the tropics, is the most favourable for producing large atmospheric $\mathrm{CO}_{2}$ decreases, because these tropical continental masses experienced huge precipitation and massive erosion, creating a large sink of atmospheric $\mathrm{CO}_{2}$ through silicate weathering as demonstrated by Donnadieu et al. (2004a). That major $\mathrm{CO}_{2}$ decrease (Fig. 5) is consistent with a drastic cooling that finally shifted the Earth towards a snowball Earth. To escape such a situation, greenhouse warming from volcanic $\mathrm{CO}_{2}$ stored during several million years in the atmosphere is certainly a robust countermechanism (Kirschvink 1992; Hoffman et al. 1998). Nevertheless, it has been shown recently (Le Hir et al. 2008a, b) that, first, the concept of no interaction of atmospheric $\mathrm{CO}_{2}$ with oceans is difficult to maintain and, second, that the acidification of the surface oceans due to enormous quantities of $\mathrm{CO}_{2}$ suddenly in contact with oceans depleted of $\mathrm{CO}_{2}$ when the sea ice melts is inconsistent with biological evolution (Le Hir et al. 2008a). For these reasons, the behaviour of the carbon cycle during and after a snowball Earth has been substantially modified in the last few years. Le Hir et al. (2008c) showed that atmospheric $\mathrm{CO}_{2}$ has to penetrate the ocean during a snowball Earth period, while Pierrehumbert (2004) showed that the threshold in $\mathrm{CO}_{2}$ necessary to melt the 

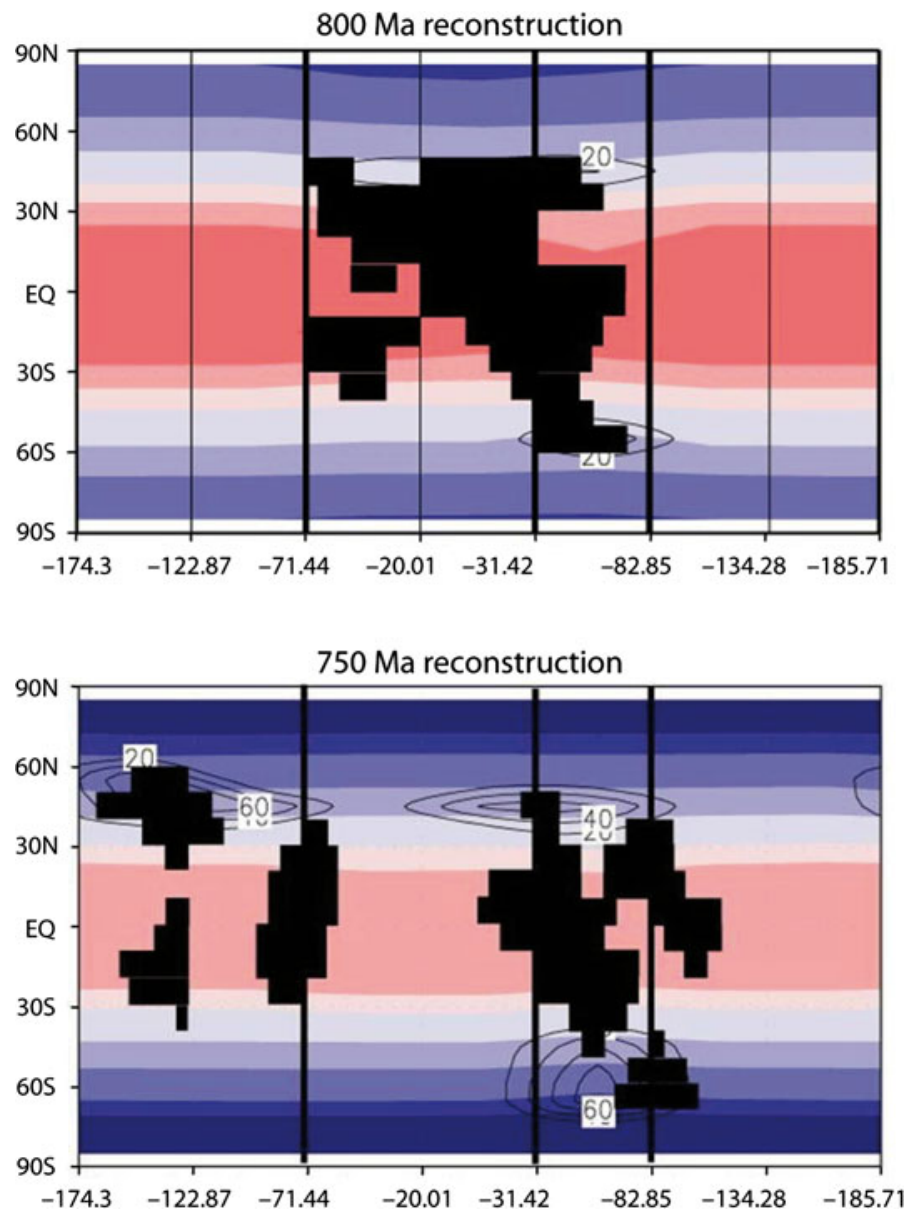

Fig. 5 Top panel annual mean temperature (degrees Celsius) reconstructed for the geological context of $800 \mathrm{Ma} \mathrm{BP}$ with the Rodinia supercontinent standing in the Equatorial region. The atmospheric $\mathrm{CO}_{2}$ concentration introduced in the climate $/ \mathrm{CO}_{2}$ model is $1,800 \mathrm{ppm}$. Bottom panel Annual mean temperatures $50 \mathrm{Ma}$ later, i.e., $750 \mathrm{Ma}$ BP. Rodinia has broken into several plates, all of them lying in the tropical band. This configuration corresponds to optimal weathering, leading to a computed drop in $\mathrm{CO}_{2}$ of $1,300 \mathrm{ppm}$, which corresponds to an equilibrium value of $500 \mathrm{ppm}$ at $750 \mathrm{Ma}$ (in the $750 \mathrm{Ma}$ reconstruction, the isolines represent the temperature difference between $800 \mathrm{Ma}$ and $750 \mathrm{Ma}$ ). (From Y. Donnadieu, Yannick.Donnadieu@1sce.ipsl.fr, LSCE, France)

ice was much higher than predicted. The amount of atmospheric carbon dioxide following these glaciations kept evolving with tectonic activity during the last $500 \mathrm{Ma}$. However, the Sun's luminosity that increased to a value of about 5\% higher today than at the end of the Cambrian Period (Fig. 2) was able to compensate the decay of atmospheric $\mathrm{CO}_{2}$, preventing the re-occurrence of a snowball Earth.

\section{Climate Evolution Since the Precambrian (540 Ma)}

The interrelationship between tectonics, climate, and the carbon cycle has played a major role in the regulation of and variation in atmospheric carbon dioxide most of the time. That 


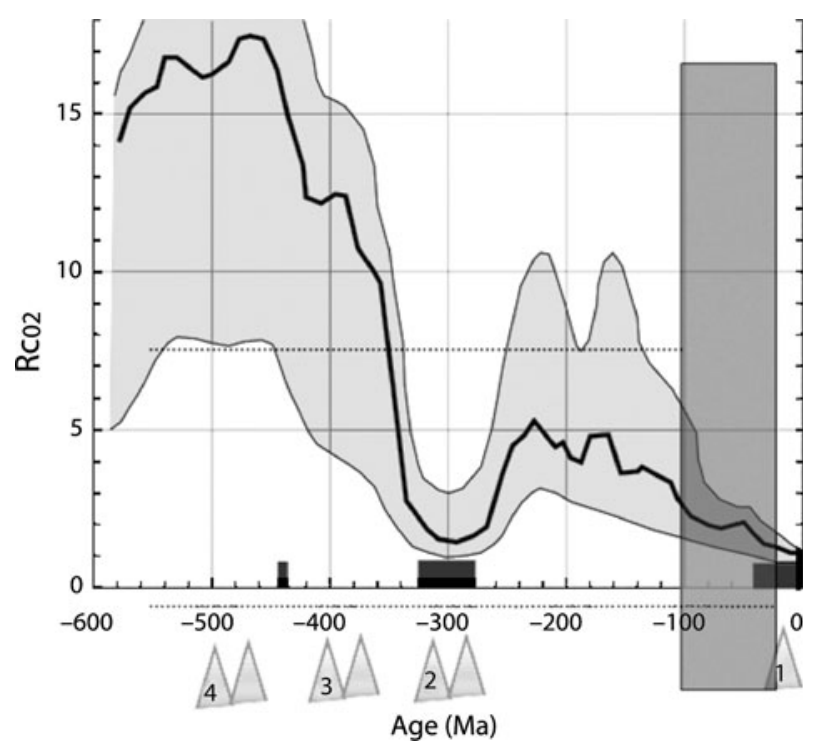

Fig. 6 This curve depicts the most recent results from the GEOCARB model of Berner for the evolution of $\mathrm{CO}_{2}$ concentration in units of PAL $(1 \mathrm{PAL}=280 \mathrm{ppm})$. The grey envelope shows the importance of uncertainties. The window inside the vertical lines corresponds to the Cretaceous-Palaeocene period. (From Berner 1994)

regulation tends to maintain a rather warm climate. Ice sheet build-ups are therefore rare events (Ramstein et al. 2004b). The Paleozoic era that follows the Cambrian (543-250 Ma) experienced a continuous but not linear decrease in temperature and in atmospheric $\mathrm{CO}_{2}$. Whereas the reconstructions of atmospheric $\mathrm{CO}_{2}$ concentrations are very scarce (Royer 2006; Knoll 2004), a decrease from 20 PAL to 10 PAL between the beginning and the end of the Paleozoic (Fig. 6) seems to be contemporaneous with the Hirnantian glaciation (Trotter et al. 2008). This glaciation has for long been difficult to explain because it occurred in a period of high concentration of atmospheric $\mathrm{CO}_{2}$ over a long time (that spans from $500 \mathrm{ka}$ to several Ma). The causes of the long-term cooling, which eventually led to glaciation, were not understood and are still discussed. Some hints of explanation (Kump et al. 1999) were proposed referring to phenomena associated with Taconic orogeny. The uplift of this mountain range that produced large areas covered with basalt had, as a consequence, an increase in orogenic precipitation and a decrease in atmospheric $\mathrm{CO}_{2}$. As basalt erodes 5-10 times faster than granite, these phenomena resulted in a larger $\mathrm{CO}_{2}$ sink and a long-term decrease in atmospheric $\mathrm{CO}_{2}$ (Désert et al. 2003). Nevertheless, this hypothesis has been challenged by different authors and therefore is still an open question. Nardin et al. (2011) attributed the long-term $\mathrm{CO}_{2}$ drawdown for one-third to fresh volcanic rocks (increased weathering) and two-third to tectonics. The drift in plate tectonics had, as a consequence, that a larger area of the continent was submitted to huge precipitation in the Inter-Tropical Convection Zone (ITCZ), resulting in drastically increased erosion and altogether in a decrease of atmospheric $\mathrm{CO}_{2}$. This is the context in which at the late Ordovician, the so-called Hirnantian, a glaciation might have occurred (Le Heron et al. 2007). Therefore, it seems that the onset of glaciation did require a weak atmospheric $\mathrm{CO}_{2}$ and the presence of continents at high latitude. The absolute value of atmospheric $\mathrm{CO}_{2}$ generally given is 10 PAL, however, with large uncertainties (Boucot and Gray 2001). This 


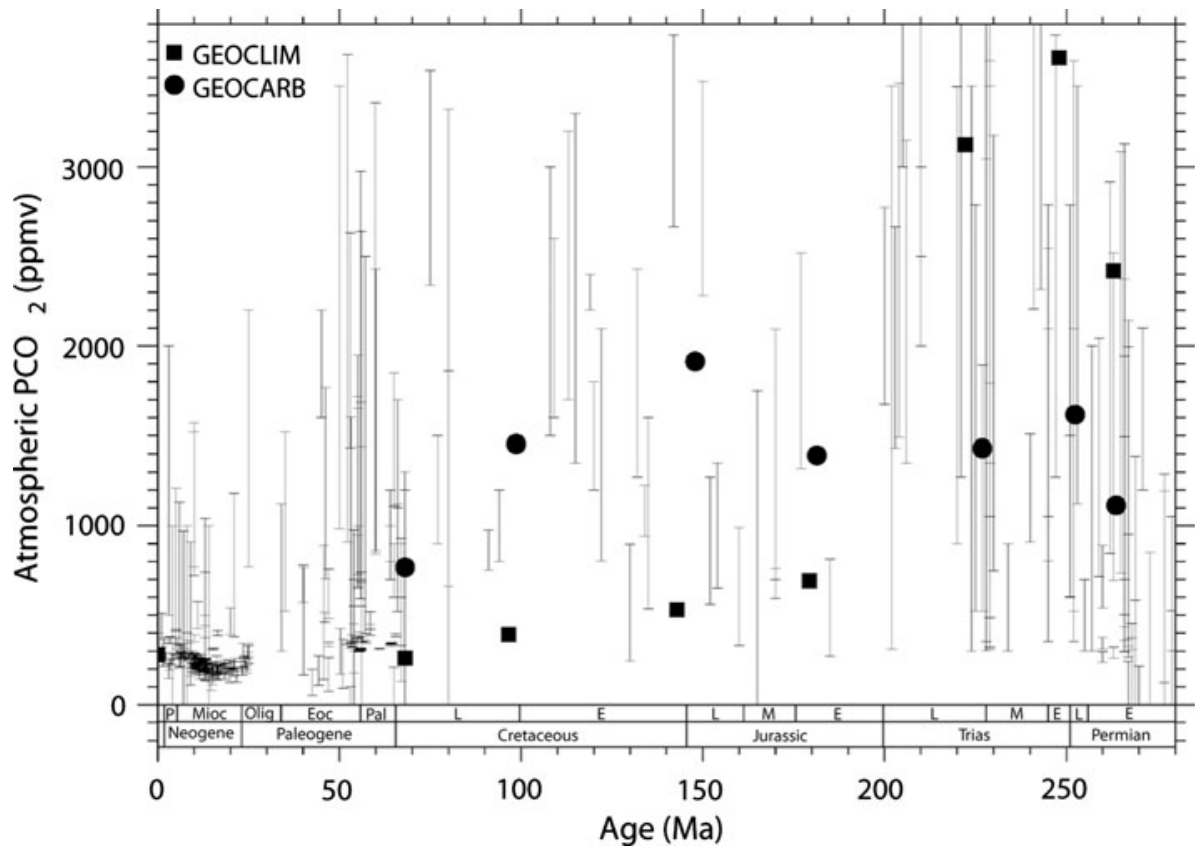

Fig. 7 Reconstruction of atmospheric $\mathrm{CO}_{2}$ concentrations for the Mesozoic and the Cenozoic since $250 \mathrm{Ma}$, derived from two different models GEOCARB (circles Berner 1994) and GEOCLIM (squares Donnadieu et al. 2006). The major difference between these two models is the evaluation of the sink. Large uncertainties remain independently of the models used. (Reconstruction from compilation by Royer D.A. 2006)

value is rather large, but accounting for the lower insolation ( $-4 \%$ relative to present), the threshold for triggering the inception of ice sheets may have been even higher during the Paleozoic.

The last important glaciation occurred at the Permo-Carboniferous boundary at $\approx 300 \mathrm{Ma}$ BP due to both a low atmospheric carbon dioxide content (Figs. 6, 7) and paleogeography, since a large fraction of the continental mass was located at high latitudes in the southern hemisphere (Fig. 8a). This Permo-Carboniferous glacial phase is quite well known in comparison with previous glaciations. Glacial deposits occurred first in South America $340 \mathrm{Ma}$ ago, and the major phase of glaciation is from 320 to $285 \mathrm{Ma}$, with ultimate glacial proxy occurring at $270 \mathrm{Ma}$ in Australia. These two forcing factors were introduced in the simulations of the Permo-Carboniferous glaciation. Figure 8 shows that annual temperatures reach negative values (in degrees Celsius) over the high southern latitudes of the Pangea continent. Also plotted in Fig. 8b are the albedo values corresponding to the summer seasons showing that perennial snow cover extended throughout the whole of South Gondwana (South Africa, South America, India, Australia, and Antarctica). This result is consistent with the moraine deposits found on these continents, an observation that led Wegener (1915) to imagine that all these areas were, at that time, placed in the same location. Later on, when the Pangea drifted towards the northern hemisphere, the continental mass slowly shifted from high to low latitudes and the alteration/erosion increased, implying a severe drop of atmospheric carbon dioxide, as simulated by the GEOCLIM (climate-carbon cycle) model of Donnadieu et al. (2006). 

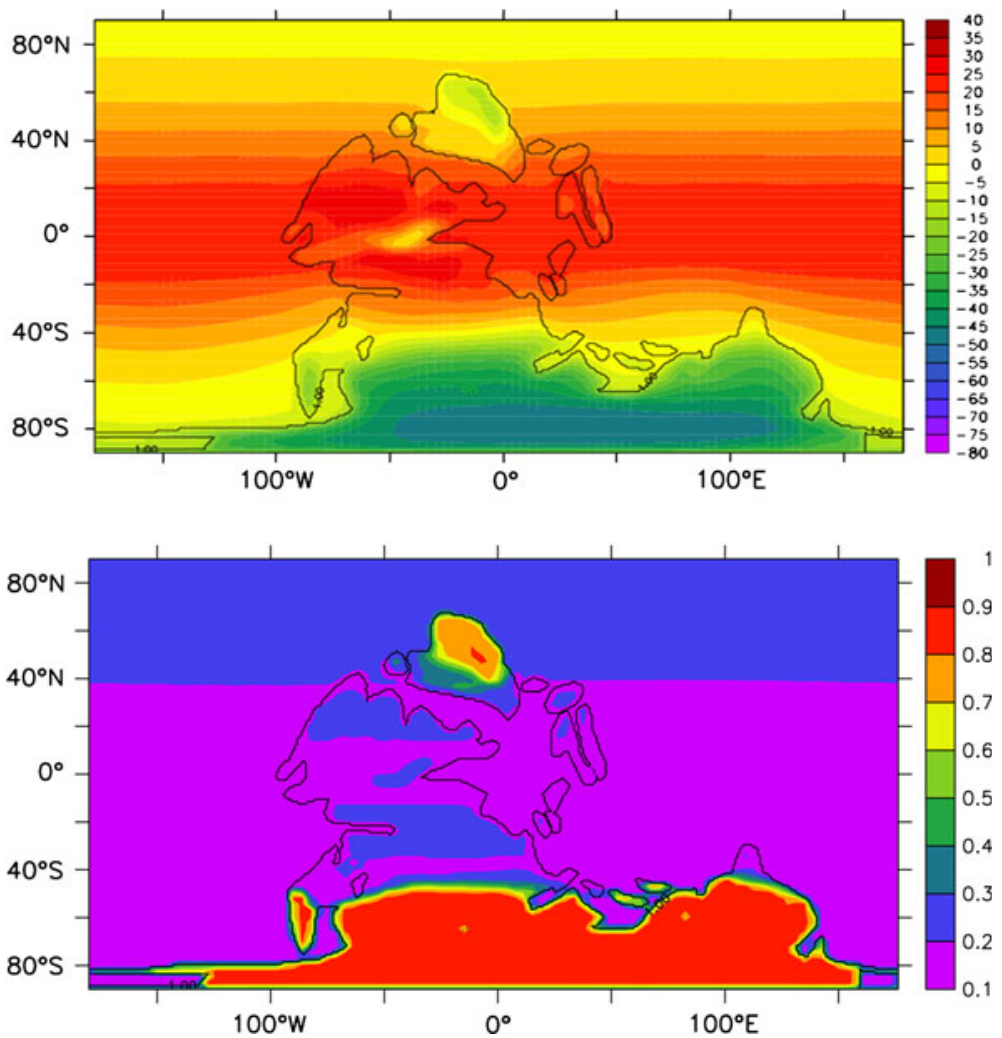

Fig. 8 During the Permo-Carboniferous, $300 \mathrm{Ma} \mathrm{BP}$, a large glaciation occurred that covered the high latitudes of South Gondwana. The top panel shows the annual mean temperature in degrees $\mathrm{C}$ and the bottom one the summer albedo (December to February) for the southern hemisphere. A high albedo due to the large snow cover over south Gondwana prevailed even during the summer season, in good agreement with geological data. (From Gilles Schneiders, LSCE, 2005)

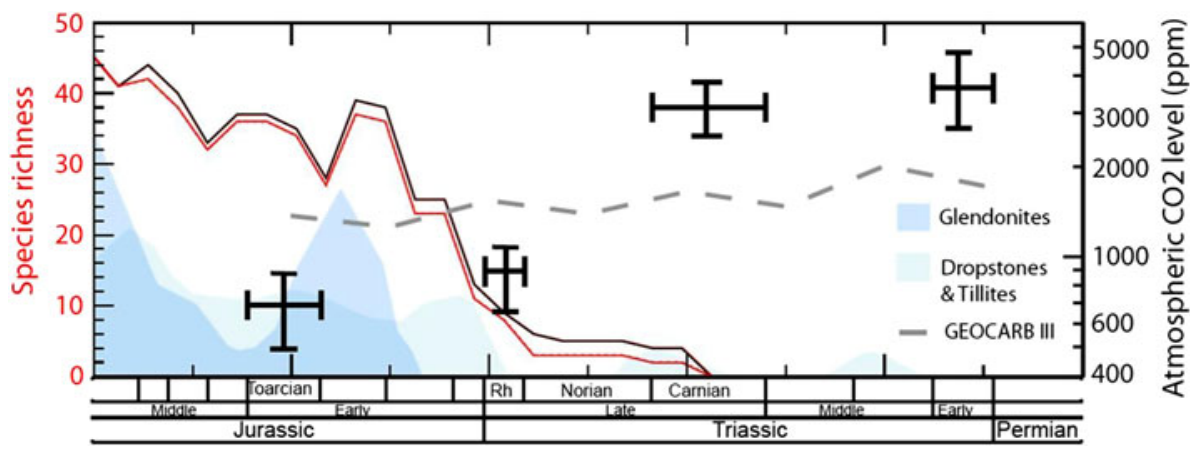

Fig. 9 Evolution of the biodiversity and of atmospheric $\mathrm{CO}_{2}$ (crosses) during the Triassic and the Jurassic periods. The red and black curves correspond to calcareous plankton evolution during the same period. The dashed curve corresponds to the GEOCARB III model. (Goddéris et al. 2008) 


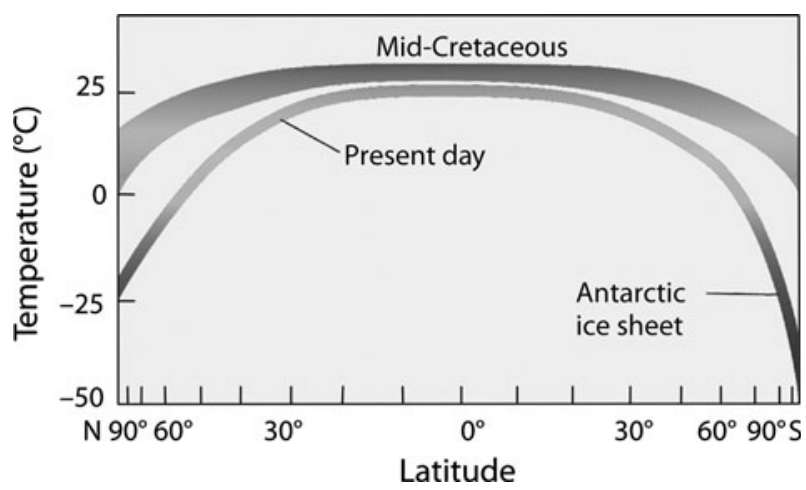

Fig. 10 Equator to pole temperature gradient derived from $\delta^{18} \mathrm{O}$ data during the mid-Cretaceous and compared with that of present-day values showing that the mid-Cretaceous temperatures are higher and more flat than present ones. It should be noticed that most of the $\delta^{18} \mathrm{O}$ data are derived from carbonate sediments resulting in rather smoother and more "flat" temperature changes with latitude. More recent $\delta^{18} \mathrm{O}$ data derived from phosphates lead to a stronger equator to pole gradient

Interestingly, the appearance of calcareous plankton corresponds to the period of large carbon dioxide decrease at the Triassic-Jurassic Transition (Rhetian: 200 Ma) (Fig. 9), which is synchronous with an increase of carbonates in the ocean providing favourable conditions for the emergence of calcareous foraminifora.

Another interesting period is that of the Mid-Cretaceous Cenomanian period $100 \mathrm{Ma}$ ago that coincided with a high level of carbon dioxide (Figs. 6, 7) and a high sea level, leading to a warm and uniform climate, with rather weak seasonal cycles and a large decrease in the equator-to-pole temperature gradient (Fluteau et al. 2007; Fig. 10). In contrast, however, to the good agreement obtained between the models and the available data for previous periods (Permo-Carboniferous and Rhaetian Periods), the rather low-temperature gradient deduced from $\delta^{18} \mathrm{O}$ measurements in calcite cannot easily be reproduced (Barron and Washington 1982). That disagreement has been shown to be due to the data reconstruction process (Pucéat et al. 2007). Regional comparison of model results with data for different Cretaceous climates has depicted reliable features (Fluteau et al. 2007).

During the Cenozoic era (65-2.6 Ma), the atmospheric $\mathrm{CO}_{2}$ decreases from 4 PAL to 1 PAL and the temperature tends to drop. A major shift from a warm to a cold climate did occur $34 \mathrm{Ma}$ ago with the onset of the Antarctic glaciation. Different model simulations have shown that the most important feature that explains this shift is in fact a decrease in atmospheric carbon dioxide (DeConto and Pollard 2003; Pagani et al. 2005; Fig. 11). Moreover, the opening of the Drake Passage, between South America and Antarctica, also played a role in this transition. Greenland's glaciation occurred only $3 \mathrm{Ma}$ ago. If the most recent evaluations of the different forcing factors (carbon dioxide drawdown, Rockies uplift, Panama Passage closure and changes in tropical ocean dynamics) show their contribution to explain the Pliocene climate; nevertheless, carbon dioxide alone is the major player in explaining Greenland's inception (Lunt 2008).

\section{The Last Million Year's Climate}

Since Greenland's glaciation $3 \mathrm{Ma}$ ago, the climate in the northern hemisphere has changed drastically, with first a period of successive ice sheets build-ups and decays with a 


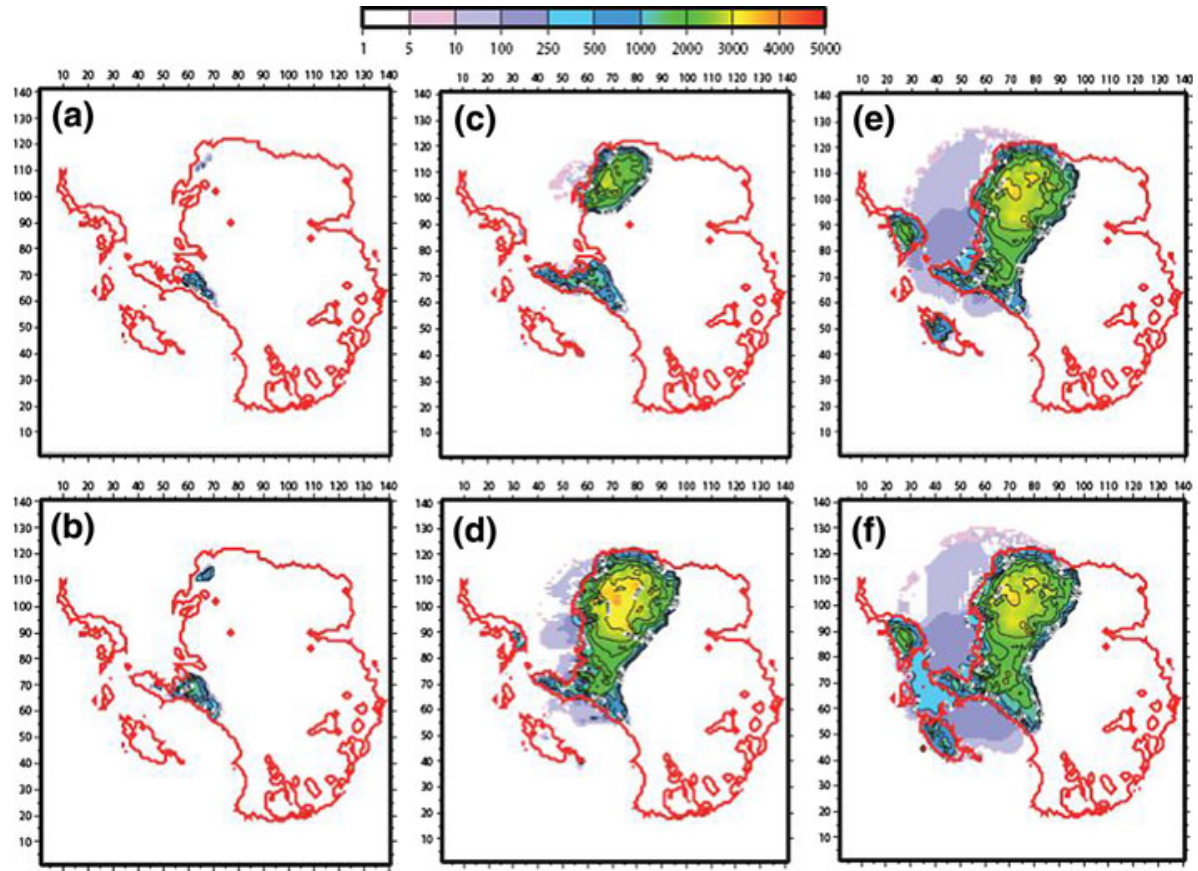

Fig. 11 Antarctic ice sheet (AIS) climate-cryosphere topography for different atmospheric $\mathrm{CO}_{2}$ concentrations and different Drake Passage (DP) configurations (fully coupled CLIMBER-GRISLI experiments). The two left panels show the AIS derived using a $\mathrm{pCO}_{2}$ set to $4 \mathrm{PAL}$ in case of a closed DP (top a) and open DP (bottom b). The middle panels show the AIS topography for $\mathrm{pCO}_{2}$ set to 4 PAL for the case of a closed DP (c) and open DP (d), respectively. The right panels represent the AIS obtained for $\mathrm{pCO}_{2}$ set to $2 \mathrm{PAL}$, with closed DP (e) and open DP (f). The ice sheet thickness is expressed in [m]. The red line represents the grounding line; it is possible to note the presence of ice shelves for the simulations (c) to (f). (From Bonelli et al. 2009)

periodicity of $40 \mathrm{ka}$, and since around 1.2 Ma ago a periodicity of $100 \mathrm{ka}$ (Paillard 2008). For that last period, hopefully, we can measure the temperature as well as methane and carbon dioxide levels through the analysis of successive layers of Antarctic ice coresglaciologists even hope to be able to go back as far as 1.5 million years (Jouzel and Masson-Delmotte 2010). This is a huge progress in contrast to the long past, for which the partial pressure of carbon dioxide was indirectly deduced from various indicators such as boron isotopes or stomata with much larger uncertainties (Figs. 6, 7). As shown in Fig. 12, the different cycles are indeed not similar in terms of temperature and greenhouse gases, and there are still many unsolved questions to properly understand the climate of the Quaternary. The last glacial-interglacial cycle from $130 \mathrm{ka}$ BP to present is certainly the best documented. Using a model of intermediate complexity (Petoukhov et al. 2000) that allows runs of long simulations coupled with ice sheet models, Ritz et al. (1997) and Bonelli et al. (2009) have succeeded in simulating altogether: the onset of glaciations (115 ka BP), the paroxysm at the last glacial maximum (21 ka BP), the fast decay of the ice sheets and the more stable climate of the Holocene Period (last $10 \mathrm{ka}$ ) (Waelbroeck et al. 2002). Figure 13 allows a comparison between the associated sea-level variations as reconstructed from data and from models (Bonelli et al. 2009). 


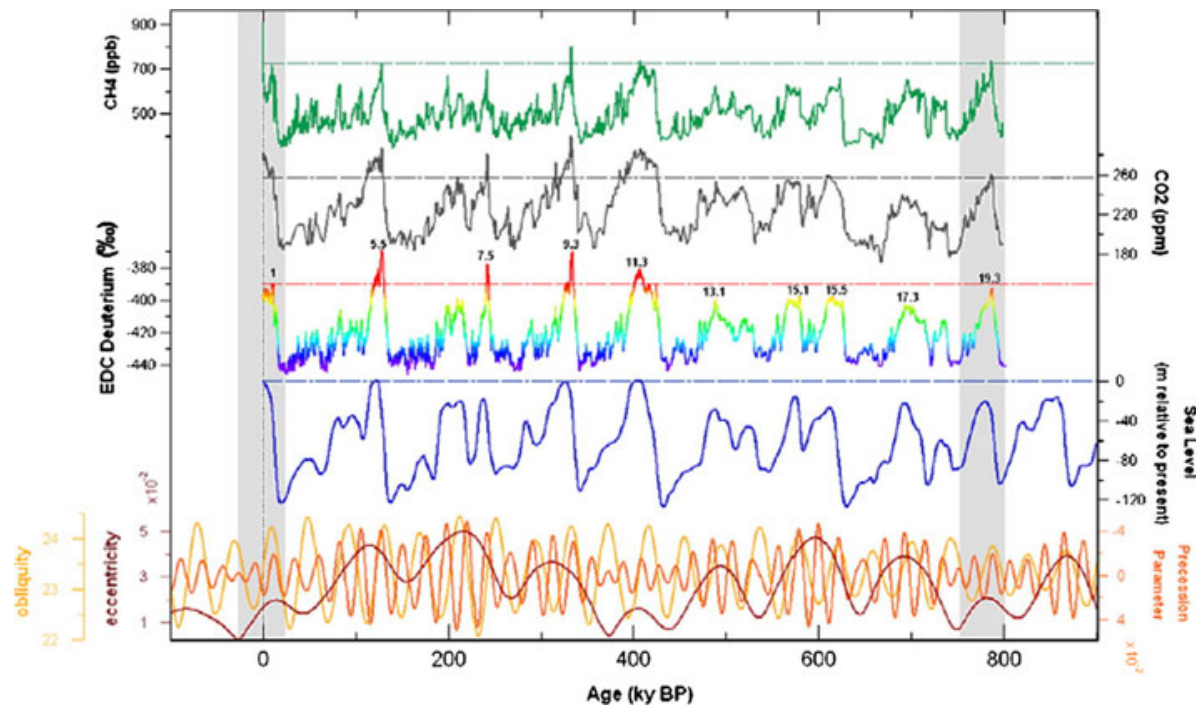

Fig. 12 From top to bottom Antarctic records of atmospheric methane concentration (ppb) (Loulergue et al. 2008), atmospheric carbon dioxide concentration (ppm) (Petit et al. 1999) (Siengenthaler et al. 2005) (Lüthi et al. 2008), and deuterium, a proxy for Antarctic temperature (Jouzel et al. 2007), (Masson-Delmotte et al. 2010). They are compared with the estimates of past changes in sea level (Bintanja et al. 2005) derived from a stack of marine records (Lisiecki and Raymo 2005) and with the past variations in the Earth's orbital parameters, eccentricity, precession parameter, and obliquity. Data are displayed as a function of time in thousands of years before 1950 (ka before present). (From Pol et al. 2010)

Indeed, being able to simulate a global cycle correctly leads to investigating the longterm behaviour of present-day ice sheets. Indeed, there is a natural variability induced by volcanic eruptions and high-frequency insolation variations but the anthropogenic forcing is, and will be, by far the major driver for long-term climate and consequently for ice sheet behaviour in the next few centuries. Using the same models and different scenarios, we stress that for accumulated carbon dioxide emission larger than 3,000 gigatons of cumulated carbon in the atmosphere (Fig. 14), the irreversible melting of Greenland may occur (Charbit et al. 2008; Fig. 15). Moreover, this 3,000 gigatons value is certainly overestimated because many processes are too coarsely parameterized in the model. For example, the spatial resolution of $40 \mathrm{~km}$ used in the models does not allow account to be taken of some explicit physical characteristics of ice streams, which are only $4 \mathrm{~km}$ large. Moreover, the nature of the different types of sediments that lie under the ice sheet and play an essential role in the sliding process is not accounted for yet in the models. Indeed, a comparison of this simulation with satellite data shows an underestimation of the ice streams' motion for present day.

\section{Conclusions}

During this travel through the Earth's past climate, we have shown that the presence of ice sheets, namely the existence of the cryosphere, is an infrequent component of the Earth's climate system. These periods are less than 5\% of the Earth's history, but they are very exciting to document and simulate because there is strong evidence which describes them. 
(a)
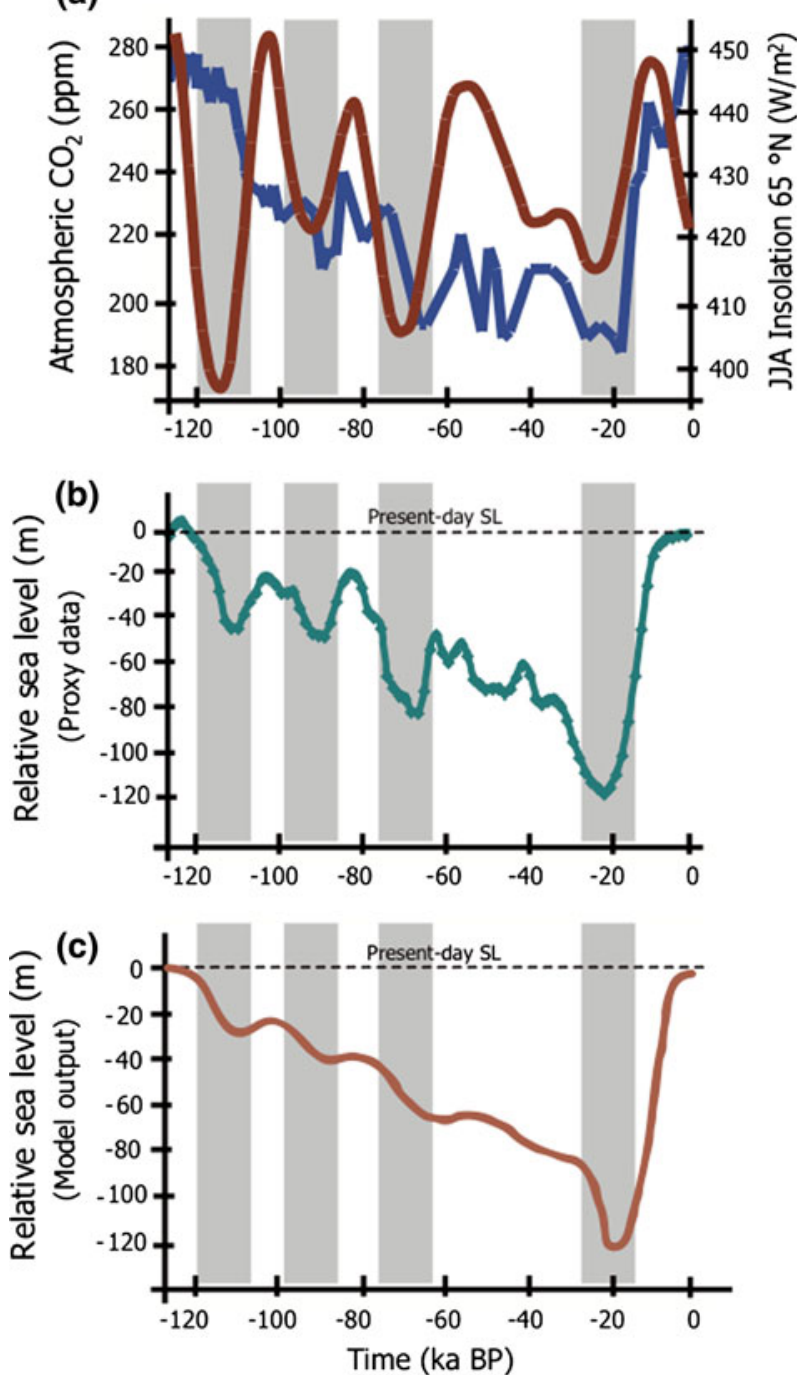

Fig. 13 Atmospheric $\mathrm{CO}_{2}$ concentrations (in ppm) and estimated see levels relative to present (in m). Panel a forcing factors used for the simulation from 126 ka to present. (1) Summer insolation at $65^{\circ} \mathrm{N}$ (right), (2) $\mathrm{CO}_{2}$ evolution as deduced from Antarctic ice cores (left). Panels $\mathbf{b}$ and $\mathbf{c}$ sea level evolution from proxy data (b) and from model simulations (c) evidencing a fairly good agreement between both estimations. (From Bonelli et al. 2009)

It is a challenging exercise for climate modellers to find the conditions under which the build-up of an ice sheet begins, is maintained and then decays.

In the long-term future, it would not be very surprising that human activity might lead to the melting of the ice sheet and later to its disappearance. This is what is foreseen in the short to mid term for Greenland and west Antarctica. First, this is because industrial development has induced extraordinarily fast and huge increases of concentrations of atmosphere. Secondly, as shown in this paper, the presence of ice sheets is not a very 
(a)

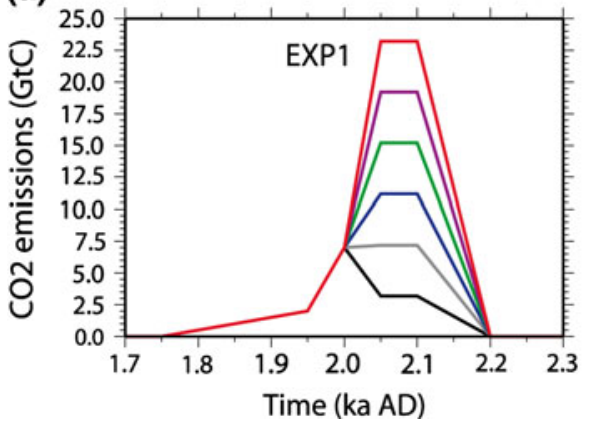

(b)

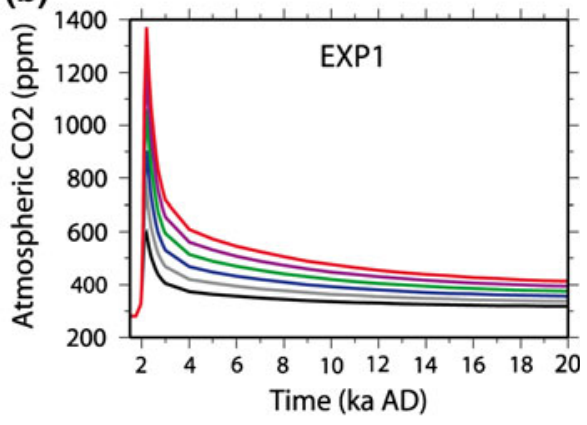

Fig. $14 \mathrm{CO}_{2}$ emission scenarios (a) and atmospheric $\mathrm{CO}_{2}$ concentration (b). $\mathrm{CO}_{2}$ emission scenarios used in the set of experiments (EXP1) (left panel) and the corresponding atmospheric $\mathrm{CO}_{2}$ concentration accounting for the natural absorption of $\mathrm{CO}_{2}$ (right panel). The cumulative emissions corresponding to all EXP 1 scenarios are 1,000 GtC (black), 1,500 GtC (grey), 2,000 GtC (blue), 2,500 GtC (green), 3,000 GtC (purple), and 3,500 GtC (red). These values are reached in the year 2200. At that time, the maximum $\mathrm{CO}_{2}$ contents in the atmosphere are 592, 748, 904, 1,060, 1,215, and 1,371 ppm, respectively. (Charbit et al. 2008)

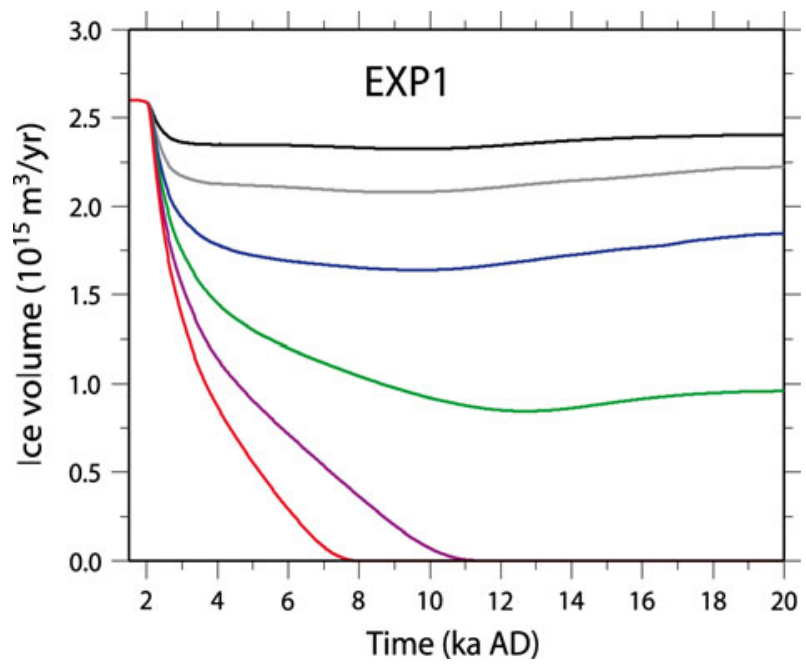

Fig. 15 Simulated ice volumes obtained with the six scenarios described in Fig. 14. Simulated ice volumes for the lowest value obtained for Greenland ice sheet show first a melting, then stabilization, whereas for a level larger than 3,000 GtC the total melting of Greenland is irreversible on the time scale of 10,000 years (10 ka). (Charbit et al. 2008)

frequent feature; they only exist under conditions of low concentartions of atmospheric carbon dioxide. Industrial development deeply perturbed the carbon cycle, rapidly transferring into the atmosphere huge amounts of carbon that was previously stored on the continents or underneath the ocean. This perturbation has been clearly evidenced by the measurements of $\mathrm{CO}_{2}$ taken since 1950 in the Earth's atmosphere. The increased concentration from $280 \mathrm{ppm}$ (preindustrial value) to $390 \mathrm{ppm}$ as of 2010 is largely outside the range (180-280 ppm) of the last million years as deduced from Antarctic ice cores. In a 
few decades, atmospheric $\mathrm{CO}_{2}$ concentration will reach $420 \mathrm{ppm}$, a level that existed tens of Ma ago, when no Greenland ice sheet was present on the Earth.

The present ongoing climate change situation seems to be different from all climate transitions described in this paper that did occur over geological timescales (Ramstein 2011). Indeed, anthropogenic perturbations happen 'instantaneously' and most of the different reservoirs-ocean surface, vegetation, and ice sheet-are not in equilibrium. Because of its intensity and abruptness, that scenario is more reminiscent of a biodiversity crisis than to the 'smooth' climate evolution of the past described in this article. On the other hand, because the perturbation is associated with human activity, there is some hope that it may be brought under control, particularly because the greenhouse gas emission scenarios for the twenty-first century have not yet been written. Unfortunately, the residence time of $\mathrm{CO}_{2}$ in the atmosphere is several hundred years (Fig. 14), and the consequences and effects of anthropogenic perturbations may still last for several centuries into the future.

Acknowledgments This chapter includes part of the recent work I did, thanks to my colleagues at LSCE: Y. Donnadieu, S. Charbit, S. Bonelli, G. Le Hir, C. Dumas and Y. Godderis at LMTG. I also want to thank JY Peterschmitt, P. Sepulchre and F. Gerry for text and illustrations. Most of the work on deep time has been funded through the ANR AccroEarth.

Open Access This article is distributed under the terms of the Creative Commons Attribution Noncommercial License which permits any noncommercial use, distribution, and reproduction in any medium, provided the original author(s) and source are credited.

\section{References}

Amiot R, Lécuyer C, Buffetaut E, Escarguel G, Fluteau F, Martineau F (2006) Oxygen isotopes from biogenic apatites suggest widespread endothermy in Cretaceous dinosaurs. Earth Planet Sci Lett 246(1-2):41-54

Barron EJ, Washington WM (1982) Cretaceous climate: a comparison of atmospheric simulations with the geologic record. Palaeogeogr Palaeoclimatol Palaeoecol 40:103-133

Berner RA (1994) 3GEOCARB II: a revised model of atmosphere $\mathrm{CO}_{2}$ over Phanerozoic time. Am J Sci 294:59-91

Bertrand P (2005) Chapitre "Vers une régulation planétaire" Des atomes aux planètes habitables de Gargaud M, Claeys P, MartinH PU Bordeaux. Collection: L'origine de la vie

Bintanja R, van de Wal R, Oerlemans J (2005) Modelled atmospheric temperatures and global sea levels over the past million years. Nature 437:125-128

Bonelli S, Charbit S, Ramstein G, Kageyama M, Woillez MN, Dumas C (2009) Investigating the evolution of major Northern hemisphere ice sheets during the last glacial-interglacial cycle. Clim Past 5:329-345

Boucot AJ, Gray J (2001) A critique of Phanerozoic climatic models involving changes in the $\mathrm{CO}_{2}$ content of the atmosphere. Earth-Sci Rev 56:1-159

Catling DC, Claire MW (2005) How Earth's atmosphere evolved to an oxic state: a status report. Earth Planet Sci Lett 237:1-20

Charbit S, Paillard D, Ramstein G (2008) Amount of $\mathrm{CO}_{2}$ emissions irreversibly leading to the total melting of Greenland. Geophys Res Lett 35:L12503. doi:10.1029/2008GL033472

Cogné JP, Humler E (2004) Temporal variation of oceanic spreading and crustal production rates during the last 180 My. Earth Planet Sci Lett 227:427-439

Crowell JC (1999) Pre-mesozoic ice ages: their bearing on understanding the climate system. Geological Society of America, Boulder. GSA Memoir, 192

DeConto R, Pollard D (2003) Rapid Cenozoic glaciation of Antarctica induced by declining atmospheric $\mathrm{CO}_{2}$. Nature 421:245-249

Désert J-M, Vidal-Madjar A, Lecavelier des Étangs A, Hébrard G, Ballester G, Ferlet R, Mayor M (2003) The data analysis of HD209458 Ly-alpha transit occultation. In: Beaulieu J-P, Lecavelier des Etangs A, 
Terquem C (eds) Proceedings of the XIXth IAP Colloquium "Extrasolar planets: today and tomorrow". ASP, San Francisco, 2 pp (arXiv:astro-ph/0312383)

Dickens GR (2003) Rethinking the global carbon cycle with a large, dynamic and microbially mediated gas hydrate capacitor. Earth Planet Sci Lett 213(3-4):169-183

Dickens GR, Francis JM (2004) Comment: a case for a comet impact trigger for the Paleocene/Eocene thermal maximum and carbon isotope excursion. Earth Planet Sci Lett 217:197-200

Donnadieu Y, Ramstein G, Fluteau F, Besse J, Meert J (2002) Is high obliquity a plausible cause for Neoproterozoic glaciations? Geophy Res Lett 29(23), Article number 2127. doi: 10.1029/2002GL015902

Donnadieu Y, Goddéris Y, Ramstein G, Nédelec A, Meert JG (2004a) Snowball Earth triggered by continental break-up through changes in runoff. Nature 428:303-306

Donnadieu Y, Ramstein G, Goddéris Y, Fluteau F (2004b) Global tectonic setting and climate of the Late Neoproterozoic: a climate-geochemical coupled study. In: Jenkins GS, McMenamin MAS, McKey CP, Sohl L (eds) The extreme proterozoic: geology, geochemistry, and climate, geophysical monograph 146. American Geophysical Union, Washington, DC, pp 79-89

Donnadieu Y, Godderis Y, Pierrehumbert R, Dromart G, Fluteau F, Jacob R (2006) A GEOCLIM simulation of climatic and biogeochemical consequences of Pangea breakup. Geochem Geophy Geosyst 7(Q11019):21. doi:10.1029/2006GC001278

Flament N, Coltice N, Reyb PF (2008) A case for late-Archaean continental emergence from thermal evolution models and hypsometry. Earth Planet Sci Lett 275:326-336

Fluteau F, Ramstein G, Besse J, Guiraud R, Masse JP (2007) Impacts of palaeogeography and sea level changes on Mid-Cretaceous climate. Palaeogeogr Palaeoclimatol Palaeoecol 247(3-4):357-381

Frakes LA, Francis JE, Syktus JI (1992) Climate modes of the phanerozoic: the history of the earth's climate over the past 600 million years. Cambridge University Press, 274 pp

Goddéris Y, Donnadieu Y, Dessert C, Dupré B, Fluteau F, François LM, Meert J, Nédélec A, Ramstein G (2007) Coupled modeling of global carbon cycle and climate in the Neoproterozoic: links between Rodinia breakup and major glaciations. Comptes Rendus Geosci 339(3-4):212-222

Goddéris Y, Donnadieu Y, De Vargas C, Pierrehumbert RT, Dromart G, Van de Schootbrugge B (2008) Causal or casual link between the rise of nannoplankton calcification and a tectonically-driven massive decrease in Late Triassic atmospheric $\mathrm{CO}_{2}$ ? Earth Planet Sci Lett 267:247-255

Gough DO (1981) Solar interior structure and luminosity variations. Sol Phys 74:21-34

Harland WB (1964) Evidence of Late Precambrian glaciation and its significance. In: Nairn AEM (ed) Problems in palaeoclimatology, interscience. Wiley, London, pp 119-149

Hoffman PF, Schrag DP (2002) The snowball Earth hypothesis: testing the limits of global change. Terra Nova 14:129-155

Hoffman PF, Kaufman AJ, Halverson GP, Schrag DP (1998) A Neoproterozoic snowball Earth. Science 281(5381):1342-1346

Jouzel J, Masson-Delmotte V (2010) Deep ice cores: the need for going back in time. Quat Sci Rev 29(27-28), Elsevier Ltd, pp 3683-3689

Jouzel J, Masson-Delmotte V, Cattani O, Dreyfus G, Falourd S, Hoffmann G, Minster B, Nouet J, Barnola JM, Chappellaz J, Fischer H, Gallet JC, Johnsen S, Leuenberger M, Loulergue L, Luethi D, Oerter H, Parrenin F, Raisbeck G, Raynaud D, Schilt A, Schwander J, Selmo E, Souchez R, Spahni R, Stauffer B, Steffensen JP, Stenni BS, Tison JL, Werner M, Wolff E (2007) Orbital and millenial Antarctic climate variability over the past 800,000 years. Science $317: 793-796$

Kasting JF (2004) When methane made climate. Sci Am 291:78-85

Kirschvink JL (1992) Late proterozoic low-latitude global glaciation: the snowball earth. Section 2.3, In: Schopf JW, Klein C, Des Maris D (eds), The proterozoic biosphere: a multidisciplinary study. Cambridge University Press, pp 51-52

Knoll AH (2004) Life on a young planet: the first three billion years of evolution on earth. Princeton University Press, Princeton. ISBN-10: 0691120293 \#; ISBN-13: 978-0691120294

Köppen W, Wegener A (1924) Die Klimate der Geologischen Vorzeit

Kump LR, Arthur MA, Patzkowsky ME, Gibbs MT, Pinkus DS, Sheehan PM (1999) A weathering hypothesis for glaciation at high atmospheric pCO2 during the Late Ordovician. Palaeogeogr Palaeoclimatol Palaeoecol 152(1, 15):173-187

Le Heron DP, Ghienne JF, El Houicha M, Khoukhi Y, Rubino JL (2007) Maximum extent of ice sheets in Morocco during the Late Ordovician glaciation. Palaeogeogr Palaeoclimatol Palaeoecol 245:200-226

Le Hir G, Goddéris Y, Donnadieu Y, Ramstein G (2008a) A geochemical modelling study of the evolution of the chemical composition of seawater linked to a "snowball" glaciation. Biogeoscience 5:253-267

Le Hir G, Goddéris Y, Donnadieu Y, Ramstein G (2008b) A scenario for the evolution of the atmopsheric $\mathrm{pCO}_{2}$ during a snowball Earth. Geology 36(1):47-50 
Le Hir G, Donnadieu Y, Goddéris Y, Pierrehumbert RT, Halverson GP, Macouin M, Nédélec A, Ramstein G (2008c) The snowball Earth aftermath: exploring the limits of continental weathering processes. Earth Planet Sci Lett 277(3-4):453-463

Levrard B, Laskar J (2003) Climate friction and the Earth's obliquity. Geophys J Int 154:970-990

Lisiecki LE, Raymo ME (2005) A Pliocene-Pleistocene stack of 57 globally distributed benthic d180 records: Paleoceanography 20:PA1003. doi:10.1029/2004PA001071

Loulergue L, Schilt A, Spahni R, Masson-Delmotte V, Blunier T, Lemieux B, Barnola JM, Raynaud D, Stocker T, Chappelaz J (2008) Orbital and millenial-scale features of atmospheric CH4 over the last 800000 years. Nature 453:383-386

Lovelock J (2000) [1979] Gaia: a new look at life on Earth, 3rd edn. Oxford University Press. ISBN: 0-19286218-9

Lunt DJ, Foster GL, Haywood AM, Stone EJ (2008) Late Pliocene Greenland glaciation controlled by a decline in atmospheric $\mathrm{CO}_{2}$ levels. Nature 454:1102-1105

Lüthi D, Floch ML, Bereiter B, Blunier T, Barnola JM, Siegenthaler U, Raynaud D, Jouzel J, Fischer H, Kawamura K, Stocker TF (2008) High resolution carbon dioxide concentration record 650,000-800,000 years before present. Nature 453:379-382

Mareschal J-C, Jaupart C (2006) Archean thermal regime and stabilization of the cratons, in Archean geodynamic processes and environments. Geophys. Mono. 164, In: Benn K, Mareschal J-C, Condie $\mathrm{KC}$ (eds), AGU, Washington (DC), pp 61-74

Masson-Delmotte V, Stenni B, Pol K, Braconnot P, Cattani O, Falourd S, Kageyama M, Jouzel J, Landais A, Minster B, Barnola JM, Chappellaz J, Krinner G, Johnsen S, Rothlisberger R, Hansen J, Mikolajewicz U, Otto-Bliesner B (2010) EPICA Dome C record of glacial and interglacial intensities. Quat Sci Rev 29:113-128

Morbidelli A, Petit J-M, Gladman B (2001) A plausible cause of the late heavy bombardment. Meteorit Planet Sci 36:371-380

Nardin E, Goddéris Y, Donnadieu Y, Le Hir G, Blakey Ronald C, Pucéat E, Markus A (2011) Modeling the early Paleozoic long-term climatic trend. GSA Bulletin

Ohmoto H, Watanabe Y, Ikemi H, Poulson SR, Taylor BE (2006) Sulphur isotope evidence for an oxic Archaean atmosphere. Nature 442:908-911

Pagani M, Zachos JC et al (2005) Marked decline in atmospheric carbon dioxide concentrations during the Paleogene. Science 309(5734):600-603

Paillard D (2008) From atmosphere, to climate, to Earth system science. Interdisc Sci Rev 33(1):25-35

Petit JR, Jouzel J, Raynaud D, Barkov NI, Barnola JM, Basile I, Bender M, Chappellaz J, Davis J, Delaygue G, Delmotte M, Kotlyakov VM, Legrand M, Lipenkov VM, Lorius C, Pépin L, Ritz C, Saltzman E, Stievenard M (1999) Climate and atmospheric history of the past 420,000 years from the Vostok ice core, Antarctica. Nature 399:429-436

Petoukhov V et al (2000) CLIMBER-2: a climate system model of intermediate complexity. Part I: model description and performance for present climate. Clim Dyn 16:1-17

Pierrehumbert RT (2004) High levels of atmospheric carbon dioxide necessary for the termination of global glaciation. Nature 429:646-649. doi:10.1038/nature02640

Pol K, Masson-Delmotte V, Johnsen S, Bigler M, Cattani O, Durand G, Falourd S, Jouzel J, Minster B, Parrenin F, Ritz C, Steen-Larsen HC, Stenni B (2010) New MIS 19 EPICA Dome C high resolution deuterium data: hints for a problematic preservation of climate variability at sub-millenial scale in the “oldest ice”. Earth Planet Sci Lett 298:95-103

Pucéat E, Lécuyer C, Donnadieu Y, Naveau P, Cappetta H, Ramstein G, Huber BT, Kriwet J (2007) Fish tooth $\delta^{18} \mathrm{O}$ revising Late Cretaceous meridional upper ocean water temperature gradients. Geology $35(2): 107-110$

Ramstein G (2011) Origins and evolution of life: an astrobiological perspective, chapter "Climate of the Earth”, Cambridge Astrobiology. Cambridge University Press, Cambridge. doi: 10.1017/CBO9780511933875.014

Ramstein G, Donnadieu Y, Goddéris Y (2004a) Proterozoic glaciations. Comptes Rendus Geosci 336(7-8):639-646

Ramstein G, Khodri M, Donnadieu Y, Goddéris Y (2004b) Impact of the hydrological cycle on past climate changes: three illustrations at different time scales. Comptes Rendus Geosci 337(1-2):125-137

Ritz C et al (1997) Sensitivity of a Greenland ice sheet model to ice flow and ablation parameters: consequences for the evolution through the last climatic cycle. Clim Dyn 13:11-24

Robert F, Chaussidon M (2006) A Palaeotemperature curve for the Precambrian oceans based on silicon isotopes in cherts. Nature 443:969-972

Rosing MT, Bird DK, Sleep NH, Bjerrum CJ (2010) No climate paradox under the faint early Sun. Nat Lett 464:744-747 
Royer DL (2006) $\mathrm{CO}_{2}$-forced climate thresholds during the Phanerozoic. Geochim Cosmochim Acta 70:5665-5675

Rye R, Kuo P, Holland HD (1995) Atmospheric carbon dioxide concentrations before 2.2 billion years ago. Nature 378:603-605

Sagan C, Mullen G (1972) Earth and mars: evolution of atmospheres and temperatures. Science 177:52-56

Shields GA, Kasting JF (2007) Brief communication arising. Nature 447:E1

Siengenthaler U, Stocker TF, Monnin E, Lüthi D, Schwander J, Stauffer B, Raynaud D, Barnola J-M, Fischer H, Masson-Delmotte V, Jouzel J (2005) Stable carbon cycle-climate relationship during the last Pleistocene. Science 310:1313-1317

Trotter JA, Williams IS, Barnes CR, Lécuyer C, Nicoll RS (2008) Did cooling oceans trigger ordovician biodiversification? Evidence from conodont thermometry. Science 321(5888):550-554

Waelbroeck C, Labeyrie L et al (2002) Sea-level and deep water temperature changes 906 derived from benthic foraminifera isotopic records. Quat Sci Rev 21(1-3):907, 295-305

Walker JCG, Hays PB, Kasting JF (1981) A negative feedback mechanism for the long-term stabilization of Earth's surface temperature. J Geophys Res 86:9776-9978

Wegener A (1915) Die Entstehung der Kontinente und Oceane

Williams GE (1975) Late Precambrian glacial climate and the Earth's obliquity. Geol Mag 112:441-465

Williams DM, Kasting JF, Frakes LA (1998) Low-latitude glaciation and rapid changes in the Earth's obliquity explained by obliquity-oblateness feedback. Nature 396:453-455

Young GM, von Brunn V, Gold DJC, Minter WEL (1998) Earth's oldest reported glaciation; physical and chemical evidence from the Archean Mozaan Group ( 2.9 Ga) of South Africa. J Geol 106:523-538

Zachos J, Pagani M, Sloan L, Thomas E, Billups K (2001) Trends, rhythms, and aberrations in global climate $65 \mathrm{Ma}$ to Present. Science 292(5517):686-693. doi:10.1126/science.1059412 